УДК 616.831-003.96-021.5-008.6

\author{
О. 3. Мельнікова ${ }^{1}$ В. П. Ляшенко \\ ${ }^{1}$ Запорізький державний медичний університет \\ ${ }^{2}$ Дніпропетровський начіональний університет ім. Олеся Гончара
}

\title{
ЗМІНИ ЕЛЕКТРОГІПОКАМПОГРАМИ ТА ПОВЕДІНКОВИХ РЕАКЦЙ ЩУРІВ ПРИ ПОСИЛЕННІ ПРОТЯГОМ ТРИВАЛОГО СТРЕСУ ГАМК-ЕРГІЧНИХ МЕХАНІЗМІВ МОЗКУ
}

Проаналізовано зміни потужностей хвиль електрогіпокампограми (ЕГпГ) щурів та їі спектральної композиції при посиленні протягом тривалого стресу активності ГАМК-ергічних механізмів мозку за допомогою гідазепаму та пірацетаму відносно значень показників ЕГпГ при ізольованому стресовому впливі. Встановлено двофазну динаміку вказаних змін, характер якої свідчить про адаптогенну дію застосованих препаратів. Модуляція центральних процесів при тривалому стресі та посиленні на його фоні ГАМК-ергічних механізмів мозку супроводжувалась змінами поведінкових реакцій тварин.

$$
\begin{gathered}
\text { О. З. Мельникова }{ }^{1} \text {, В. П. Ляшенко }{ }^{2} \\
\text { 'Запорожский государственный медииинский университет } \\
\text { ²Депропетровский начиональный университет им. Олеся Гончара } \\
\text { ИЗМЕНЕНИЯ ЭЛЕКТРОГИППОКАМПОГРАММЫ } \\
\text { И ПОВЕДЕНЧЕСКИХ РЕАКЦИЙ КРЫС ПРИ УСИЛЕНИИ } \\
\text { В ТЕЧЕНИЕ ДЛИТЕЛЬНОГО СТРЕССА } \\
\text { ГАМК-ЭРГИЧЕСКИХ МЕХАНИЗМОВ МОЗГА }
\end{gathered}
$$

\begin{abstract}
Проанализированы изменения мощностей волн электрогиппокампограммы (ЭГпГ) крыс и ее спектральной композиции при усилении на протяжении длительного стресса активности ГАМКэргических механизмов мозга с помощью гидазепама и пирацетама относительно значений показателей ЭГпГ при изолированном стрессовом воздействии. Установлена двухфазная динамика указанных изменений, характер которой свидетельствует об адаптогенном действии указанных препаратов. Модуляция центральных процессов при длительном стрессе и усилении на его фоне ГАМКэргических механизмов мозга сопровождалась изменениями поведенческих реакций животных.

$$
\begin{gathered}
\text { O. Z. Melnikova }{ }^{1}, \text { V. P. Lyashenko }{ }^{2} \\
\text { 'Zaporizhzhya State Medical University } \\
{ }^{2} \text { Oles' Honchar Dnipropetrovsk National University }
\end{gathered}
$$

\section{CHANGES OF RATS ELECTROHIPPOCAMPOGRAM AND THEIR BEHAVIORAL RESPONSES CAUSED BY AMPLIFICATION OF BRAIN GABA-ERGIC MECHANISMS DURING PROLONGED STRESS}

The changes of waves' power and spectral composition of electrohippocampogram (EHpG) were analyzed in rats which brain GABA-ergic mechanisms increased by gidazepam and pyracetam during prolonged stress comparatively to the indices of EHpG under isolated affective influence. The nature of two-

(C) О. 3. Мельнікова, В. П. Ляшенко, 2012 
phase dynamics of the changes could indicate an adaptogenic action of drugs. It's shown that modulation of central processes during prolonged stress and amplification of brain GABA-ergic mechanisms are accompanied by the changes of the animals' behavioral reactions.

\section{Вступ}

ГАМК-система мозку служить однією $з$ його стрес-лімітувальних систем, від потужності яких залежать наслідки стресу для організму [5-8]. Терміналі ГАМКергічних нейронів широко розповсюджені у різних структурах мозку, в яких гамааміномасляна кислота служить гальмівним медіатором [8; 9]. Вважають, що стреслімітувальна функція ГАМК пов'язана з обмеженням надмірного збудження центральних стресреалізуючих структур і їх гормонально-медіаторних механізмів [6]. Однак при хронічному (тривалому) стресі, очевидно, реалізація вказаної функції ГАМК не має сенсу, оскільки у мозку не виникає надмірного збудження, а стресовий чинник продовжує діяти. Проте виявлено, що спільною ланкою патогенезу багатьох стресогенних порушень, викликаних тривалим стресом, служить саме недостатність ГАМКсистеми [5]. Причини цього можуть бути пов' язані з великим ії значенням в енергетичному забезпеченні мозку [6; 8], у механізмах його фонового електрогенезу [3; 7].

Між указаними аспектами функціонування головного мозку існує тісний зв'язок: основну частину енергетичних витрат мозку (навіть у стані фізіологічного спокою) складає підтримання ФЕА мозкових утворень [3], яку вважають передумовою всіх видів діяльності організму. Протягом хронічного стресу розвивається стан енергодефіциту мозку [7], а також глибокі зміни його фонового електрогенезу [3]. Однак співвідношення між цими наслідками тривалого стресового впливу та участь у них ГАМК-ергічних механізмів не визначені, хоча дослідження цього питання могло б надати нові шляхи профілактики та корекції стресогенних порушень в організмі [6].

3'ясування поставленого питання ми вважали доцільним провести, реєструючи ФЕА гіпокампа щурів, оскільки функціонування цієї структури тісно пов'язане 3 ГАМК-системою мозку [8; 9; 15]. Саме у гіпокампі при хронічному стресі у першу чергу розвиваються нейродегенеративні процеси, в яких основну роль відіграють тривалі зміни мембранного потенціалу нейронів, що потенціює ексайтотоксичну дію глутамату на нервові клітини [14-18]. Ефективність відновлення електричного гомеостазу, у здійсненні якого провідне значення має ГАМК, виявляється недостатньою. Посилюючи активність ГАМК-ергічних механізмів із самого початку дії стресогенного фактора, ми могли оцінити прояви та роль їх дії на ФЕА гіпокампа, а також на рухову та дослідницьку активність щурів, тобто на поведінку тварин, у регуляції якої бере участь вказана структура мозку [12].

Мета цієї роботи - з'ясувати зміни характеристик ФЕА гіпокампа (електрогіпокампограми) і показників рухової та дослідницької активності щурів, які тривалий час перебували у стресогенних умовах, при застосуванні гідазепаму та пірацетаму, що посилюють активність ГАМК-системи мозку.

\section{Матеріал і методи досліджень}

Експерименти здійснювали на нелінійних білих щурах-самцях відповідно до існуючих міжнародних вимог і норм гуманного ставлення до тварин. На початку дослідження вони мали вагу 125-140 г. Тваринам $(n=63)$ протягом 21 тижня створювали стресогенні умови шляхом суттєвого обмеження життєвого простору до 80$100 \mathrm{~cm}^{2}$ на одну особину.

Тварин поділили на три групи. Перша 3 них складалась зі щурів, які на фоні стресу не отримували модуляторів ГАМК-ергічної системи мозку (стресова група). 
Щурам другої групи 3 початку і до кінця дослідження на фоні стресу вводили гідазепам у дозі 25 мг/кг/добу, який потенціює вплив ГАМК на мембрани нейронів, тобто посилює іï медіаторну дію [12]. Тварини третьої групи у стресогенних умовах отримували пірацетам, який має немедіаторну ГАМК-подібну дію на метаболізм і енергетику нервових клітин, у кількості 5 мг/кг/добу [12]. Усі фармакологічні речовини щурам уводили перорально вранці $\left(8^{00}-10^{00}\right)$, натще. Для цього препарати розчиняли в 1 мл фізіологічного розчину. Тваринам стресової групи вводили таку саму його кількість у чистому вигляді.

Тестування поведінкових реакцій щурів проводили за методикою «відкритого поля». Для цього використовували не закриту зверху пластикову камеру розміром $80 \times 80$ × 40, дно якої було розграфлене на 25 квадратів. Дотримувались загальноприйнятих правил тестування тварин у «відкритому полі» [1]. На початку досліду тварину розміщали в центрі відкритого поля, а потім підраховували загальну кількість відвіданих нею квадратів (показник горизонтальної рухової активності) і кількість центральних квадратів (характеристика дослідницької активності). Тестування тривало 3 хвилини.

Відведення електрогіпокампограми проводили у підгрупах із трьох тварин, відібраних із кожної групи 3 інтервалом у три тижні упродовж усього періоду дослідження. Хірургічна підготовка до відведення ЕГпГ виконувалася після внутрішньочеревинного уведення 20 мг/кг кетаміну та 50 мг/кг тіопенталу натрію. Після фіксації тварини у стереотаксичному приладі та проведення трепанації черепа в гіпокамп уводили уніполярний електрод (ніхром, діаметр 100 мкм) згідно з координатами: відстань від брегми (B) - 1,4; латерально (L) 0,8 ; глибина відносно інтерауральної осі (I) 4,0 [10]. Референтний електрод закріплювали на вушній раковині тварини. Верифікацію локалізації кінчиків електродів проводили на фронтальних зрізах мозку.

ФЕА гіпокампа реєстрували за допомогою стандартного комплексу електрофізіологічного устаткування. Записи починали, коли в електричній активності гіпокампа зникали наркотичні веретена. На кожній тварині робили по 10-12 записів тривалістю 1-2 хвилини, які у цифровому вигляді зберігали у комп'ютері. Подальшу обробку здійснювали за допомогою пакета прикладних програм у складі MathCAD 2000. Аналізували спектральні потужності $\left(\right.$ мкВ $\left.^{2}\right)$ і нормовані потужності (\%) хвиль ФЕА гіпокампа у межах загальноприйнятих частотних діапазонів [3].

Отримані результати по кожній підгрупі тварин у відповідні тижні дослідження обробляли статистично з визначенням середніх та їх помилок.

\section{Результати дослідження та їх обговорення}

Застосування на тлі стресового впливу фармацевтичних препаратів, які посилюють активність ГАМК-системи мозку, суттєво змінювало характеристики ФЕА гіпокампа стресованих тварин (рис. 1,2). При використанні гідазепаму через 3 тижні експерименту відбувалось суттєве зменшення потужностей хвиль усіх частотних діапазонів електрогіпокампограми (рис. $1, A$ ). Це могло вказувати на суттєве переважання процесів гальмування у мозку над збудженням у цей період. Через 6-9 тижнів дослідження потужності вказаних хвиль достовірно не відрізнялись від їх значень у стресовій групі тварин. Однак через 12-18 тижнів відбувалось суттєве зростання значень аналізованого показника в усіх частотних діапазонах ФЕА гіпокампа тварин гідазепамової групи. Максимально зростали потужності хвиль частотою 4-8 Гц (тих, що відносять до тета-діапазону) [3]. Через 21 тиждень потужності хвиль ФЕА гіпокампа у тварин, що отримували гідазепам, були збільшеними відносно значень стресової групи, однак незначною мірою. 


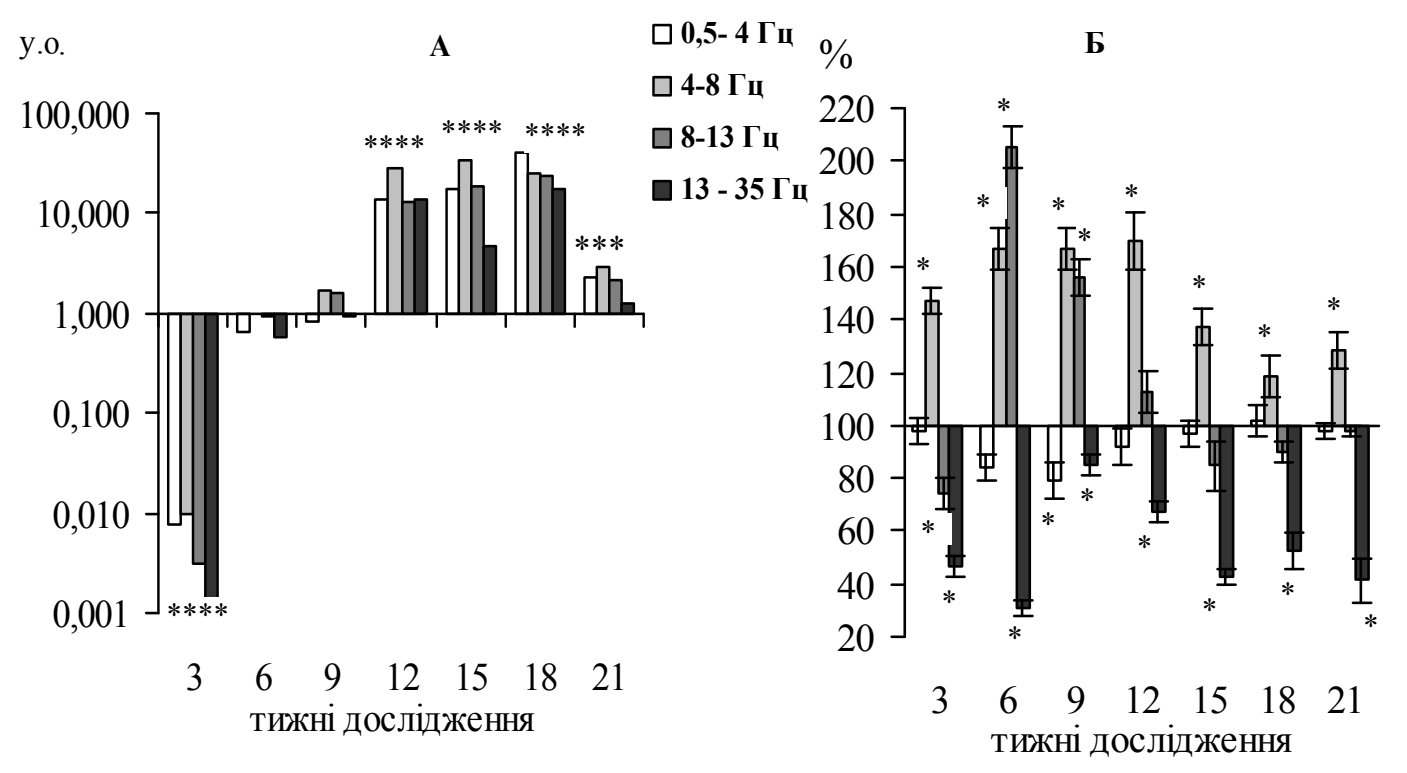

Рис. 1. Зміни абсолютних $(A)$ і нормованих $($ Б) потужностей хвиль електрогіпокампограми тварин, що отримували на фоні стресу гідазепам, відносно значень аналізованих показників у щурів стресової групи

У спектральній композиції протягом усього експерименту під впливом гідазепаму зростав відсоток хвиль частотою 4-8 Гц (рис. 1, Б). Максимальне збільшення нормованої потужності цих хвиль зафіксоване через 3-12 тижнів експерименту. Через 6-12 тижнів це супроводжувалось зростанням відсотка хвиль іншого середньочастотного діапазону (8-13 Гц), які у людини відносять до альфа-діапазону [3]. В інші терміни спостереження кількість цих хвиль у тварин гідазепамової групи була зменшеною відносно стресової групи щурів. Представленість високочастотних хвиль зменшувалась протягом усього експерименту, а низькочастотних - майже не змінювалась, хоча через 6-9 тижнів була достовірно зниженою.

Динаміка абсолютних потужностей хвиль ФЕА гіпокампа щурів при застосуванні пірацетаму відносно їх значень у тварин стресової групи (рис. 2, $A$ ) була досить подібною до динаміки цього показника для «гідазепамової» групи. Однак після зменшення потужностей хвиль усіх частот через 3 тижні дослідження вже через 6 тижнів вони під впливом пірацетаму підвищувались. Таке явище тривало до кінця дослідження, але було максимально вираженим через 12-18 тижнів спостереження.

Під впливом пірацетаму змінювалась і спектральна композиція ФЕА гіпокампа (рис. 2, Б). Вже через 3 тижні спостерігалось зростання відсотка хвиль частотою 4-8 Гц i 8-13 Гц. Це явище спостерігалось майже в усі терміни дослідження, однак найсуттєвіше - на початку дослідження (через 3-6 тижнів). Відсоток низько- та високочастотних хвиль у ФЕА гіпокампа тварин «пірацетамової» групи, навпаки, був зменшеним відносно їх величин у стресовій групі тварин протягом усього терміну спостереження. Тобто застосування пірацетаму викликало збільшення кількості середньочастотних хвиль у ФЕА гіпокампа щурів.

При посиленні ГАМК-ергічних механізмів мозку гідазепамом і пірацетамом відбувались зміни показників рухової та дослідницької активності тварин відносно їх значень у щурів стресової групи (рис. 3). У тварин «гідазепамової» групи зменшува- 
лись показники горизонтальної рухової активності протягом усього експерименту. Максимальний прояв цього явища спостерігався через 12-15 тижнів. Показники дослідницької активності тварин під впливом гідазепаму з початку експерименту та через 12-15 тижнів також зменшувались відносно відповідних значень у щурів стресової групи. Однак через 18 тижнів відбувалось їх суттєве збільшення, що спостерігалось, але меншою мірою, і через 21 тиждень дослідження.

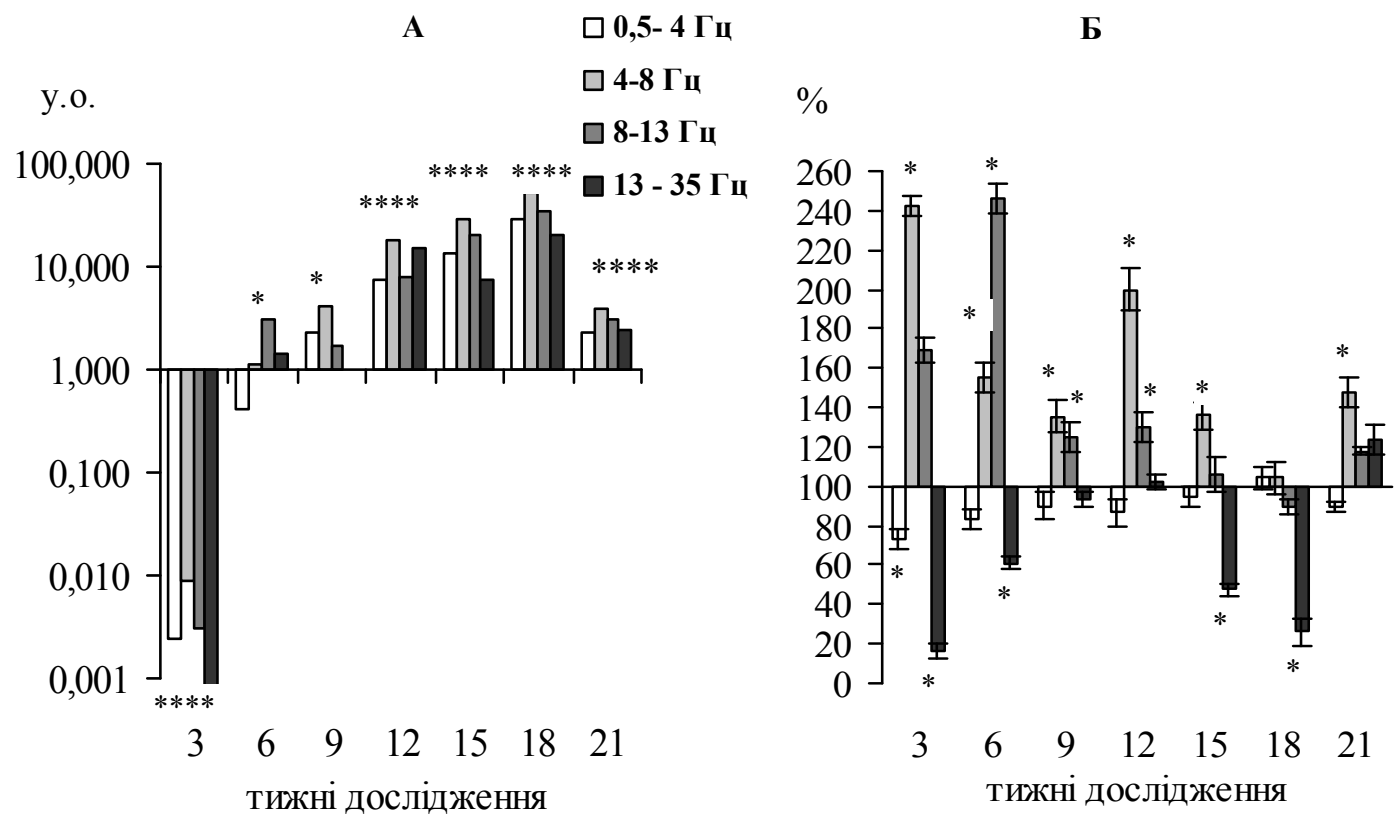

Рис. 2. Зміни абсолютних $(A)$ і нормованих (Б) потужностей хвиль електрогіпокампограми тварин, що отримували на фоні стресу пірацетам, відносно значень аналізованих показників у щурів стресової групи

При застосуванні пірацетаму горизонтальна рухова активність тварин дещо знижувалася через 3-9 тижнів експерименту відносно стресової групи. Через 12-15 тижнів відбувалось достовірне зменшення показників такої активності у щурів «пірацетамової» групи, однак через 18-21 тиждень вони відновлювались до величин, характерних для стресованих тварин. Така картина могла бути зумовлена тим, що в останніх через 12-15 тижнів горизонтальна рухова активність була підвищеною, у той час як пірацетам усував цю гіперактивність, викликану стресогенним впливом.

Зміни дослідницької активності стресованих щурів під впливом пірацетаму полягали у збільшенні іï показників протягом усього експерименту. Максимум цього впливу зафіксований через 15-21 тиждень експерименту, тобто при збільшенні терміну вживання тваринами препарату, що могло бути зумовлено його ноотропними властивостями [12].

Результати роботи можуть свідчити, що посилення активності ГАМК-ергічних механізмів мозку з початку і протягом дії стресогенних умов може суттєво моделювати перебіг стрес-реакції організму, зокрема ії прояви в ФЕА гіпокампа та у поведінці тварин. Зміни потужностей хвиль біоелектричної активності нервової структури, що досліджувалась, у тварин, які отримували препарати на фоні стресу, відбувались у дві фази відносно значень цього показника у стресовій групі тварин. 
A

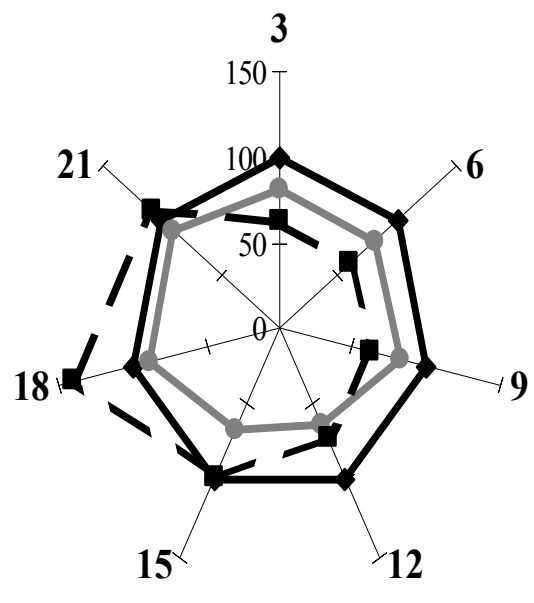

Б

3

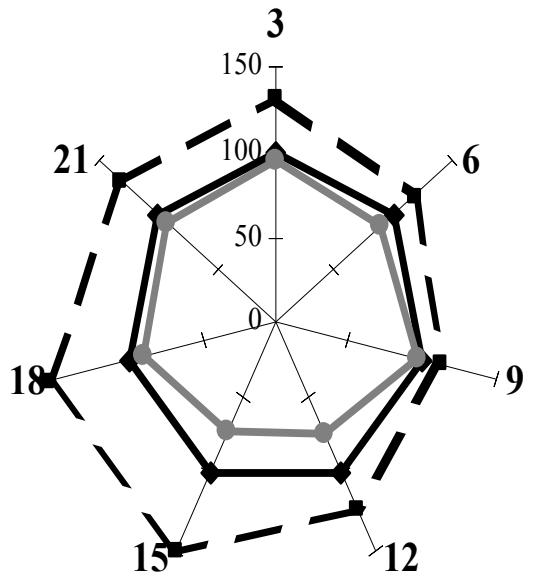

Рис. 3. Зміни показників рухової та дослідницької активності щурів, які на фоні стресу отримували гідазепам $(\boldsymbol{A})$ і пірацетам $(\boldsymbol{B})$ : цифри біля осей діаграми - тижні експерименту; на осях відкладено показники рухової та дослідницької активності щурів фармгруп відносно значень цих показників у стресовій групі (\%); безперервна чорна лінія - умовне позначення останніх

(100 \%); сіра лінія - відносні показники рухової, а пунктир - дослідницької активності тварин

Раніше нами показано, що при ізольованому стресовому впливі спостерігалась трифазна динаміка показників ФЕА гіпокампа щурів [4]. Це свідчило (з урахуванням даних [6]), що при формуванні адаптації трифазна динаміка показників стресової відповіді стає двофазною, а також про адаптогенне призначення пірацетаму [12], що посилення потужності ГАМК-системи 3 початку та протягом дії стресогенних умов сприяло адаптації до них мозку у нашому дослідженні.

Її проявом служило формування потужної ФЕА мозкових утворень із перерозподілом спектральної потужності на користь середньочастотних хвиль, у механізмах синхронізації яких ГАМК належить провідне значення. Протягом ізольованого тривалого впливу стресу, скоріше за все, активності цієї системи не вистачає на підтримання стабільного фонового електрогенезу мозку, про що можуть свідчити результати наших попередніх праць, у яких показано, що друга фаза стресу при такому впливі проявлялась у поступовому зменшенні потужностей ФЕА гіпокампа відносно контролю [4].

Зміни ФЕА гіпокампа щурів, які на тлі стресу отримували гідазепам і пірацетам, певною мірою відображались у модуляції їх поведінкових реакцій. Обидва препарати зменшували показники горизонтальної рухової активності тварин, однак при використанні гідазепаму це явище було вираженішим. У цьому, очевидно, відігравало роль потенціювання безпосередньо гальмівного впливу ГАМК у мозкових структурах, тоді як пірацетам поліпшував метаболізм і енергетику нервових клітин, не викликаючи їх гальмування. Ми можемо припустити, що саме це могло зумовлювати характер змін у нашому експерименті дослідницької активності тварин, в яких відносно велику роль відіграють процеси не тільки збудження, а й гальмування [13]. Так, на початку 
дослідження гідазепам, посилюючи гальмування, змінював співвідношення вказаних процесів, що викликало зменшення дослідницької активності тварин. У другій половині експерименту, на нашу думку, збільшення дослідницької діяльності тварин гідазепамової групи було наслідком протективної дії такого гальмування на функціональний стан нейронних ланцюгів гіпокампа і пов'язаних із ним структур головного мозку. Такий висновок може підтверджувати також збільшення дослідницької активності тварин під впливом пірацетаму із самого початку дослідження.

\section{Висновки}

1. Застосування на фоні стресового впливу гідазепаму, який посилював медіаторну дію ГАМК у мозку щурів, і пірацетаму, що чинив немедіаторну ГАМКподібну дію на метаболізм і енергетику нейронів, викликало двофазні зміни ФЕА гіпокампа стресованих тварин.

2. Зростання потужностей хвиль ФЕА гіпокампа щурів під впливом гідазепаму та пірацетаму у другій половині та до кінця дослідження могло свідчити про їх адаптогенну дію.

3. Збільшення потужності ГАМК-ергічних механізмів мозку протягом стресового впливу зумовлювало перерозподіл спектральної композиції ФЕА гіпокампа щурів на користь хвиль середньочастотних діапазонів.

4. Модуляція ФЕА гіпокампа стресованих тварин під впливом гідазепаму та пірацетаму супроводжувалась змінами їх поведінкових реакцій, що могло бути наслідком утворення певного балансу процесів збудження та гальмування, який міг сприяти відновленню функціонального стану гіпокампа.

\section{Бібліографічні посилання}

1. Буреш Я. Методики и основные эксперименты по изучению мозга и поведения / Я. Буреш, О. Бурешова, Д. П. Хьюстон. - М. : Высш. шк., 1991. - 399 с.

2. Ведяев Ф. П. Модели и механизмы эмоциональных стрессов / Ф. П. Ведяев, Т. М. Воробьева. К. : Здоров'я, 1983. - 136 с.

3. Воробьева Т. М. Электрическая активность мозга (природа, механизмы, функциональное значение) / Т. М. Воробьева, С. П. Колядко // Экспериментальная и клиническая медицина. 2007. - № 2. - С. 4-11.

4. Динаміка показників електрогіпокампограми щурів в умовах довготривалого стресу: ефекти застосування модуляторів синаптичної передачі / С. М. Лукашов, Г. Г. Сидоренко, О. 3. Мельникова та ін. // Нейрофізіол. / Neurophysiol. - 2009. - Т. 41, № 4. - С. 316-326.

5. Калуев А. В. О роли ГАМК в патогенезе тревоги и депрессии / А. В. Калуев, Д. Д. Натт // Эксп. и клин. фармакол. - 2004. - Т. 67, № 4. - С. 71-76.

6. Меерсон Ф. 3. Адаптация к стрессовым ситуациям и стрессовым нагрузкам / Ф. З. Меерсон, М. Г. Пшенникова. - М. : Медицина, 1988. - 256 с.

7. Мозг: теоретические и клинические аспекты / Под ред. В. Н. Покровского. - М. : Медицина, 2003. $-536 \mathrm{c}$.

8. Нейрохимия / Под ред. И. П. Ашмарина, П. В. Стукалова. - М. : Изд-во Ин-та био-мед. хим. PAMH, 1996. - 470 c.

9. Семьянов А. В. ГАМК-эргическое торможение в ЦНС: типы ГАМК-рецепторов и механизмы тонического ГАМК-опосредованного действия // Нейрофізіол. / Neurophysiol. - 2002. Т. 34, № 1. - С. 82-92.

10. Стереотаксический атлас мозга крыс (фронтальные сечения) / Под ред. А. Ю. Буданцева. Пущино : Аналитическая микроскопия, 2002.

11. Тодоров И. Н. Стресс, старение и их биохимическая коррекция / И.Н. Тодоров, Г. И. Тодоров. М. : Наука, 2003. - 479 с. 
12. Фармакотерапия в неврологии и психиатрии / Ред. С. Д. Энна, Д. Т. Койла. - М. : Мед. инф. агент., 2007. - С. 13-194.

13. Daniels W. M. U. The development of behavioral and endocrine abnormalities in rats after repeated exposure to direct and indirect stress / W. M. U. Daniels, J. de K. Uys, P. van Vuuren // Neuropsychiatr. Dis. Treat. - 2008. - Vol. 4, N 2. - P. 451-464.

14. De Kloet E. R. Hormones and the stressed brain // Ann. N. Y. Acad. Sci. - 2004. - Vol. 1018. - P. 1-15.

15. Frend T. F. Inhibitory control of GABA-ergic interneurons in the hippocampus / T. F. Frend, A. I. Gulyas // Can. J. Physiol. Pharmacol. - 1997. - Vol. 75, N 5. - P. 479-487.

16. Fuchs E. Chronic social stress: Effects on limbic brain structures / E. Fuchs, G. Flugge // J. Physiol. Behav. - 2003. - Vol. 79, N 3. - P. 417-427.

17. Joels M. Effect of chronic stress on structure and functions in rat hippocampus and hypothalamus // Stress. - 2004. - Vol. 7, N 4. - P. 221-231.

18. McEwen B. S. Central effects of stress hormones in heals and disease: Understanding the protective and damaging effects of stress and stress mediators // Eur. J. Pharmacol. - 2007. - Vol. 583, N 2-3. P. 174-185.

Надійшла 14.02.2012 